\title{
De impasse van het cardiometabool preventieconsult
}

$\mathrm{D}$ zorg voor cardiometabole aandoeningen in de eerste lijn is over het algemeen goed georganiseerd met up-todate zorgstandaarden en ketenzorg voor onder andere diabetes mellitus en cardiovasculair risicomanagement (CVRM). Vaak wordt deze zorg gecombineerd met programma's voor het verbeteren van de leefstijl. De zorg voor patiënten met een cardiometabole ziekte is onomstreden, maar de implementatie van preventie en vroegopsporing van cardiometabole aandoeningen is nog controversieel.

\section{INLEIDING EN HISTORISCHE ACHTERGROND}

Op dit moment wordt preventie op ad hoc basis aangeboden op diverse plekken in het land, door enkele huisartsen, bedrijfsgeneeskundige diensten, door apotheken en in pilotprojecten van verzekeraars. Vaak worden daarbij zelftests gebruikt. Recente evaluaties van initiatieven voor opsporing van mensen met een verhoogd risico op hart- en vaatziekten en chronische nierschade laten zien dat het effect groter kan zijn bij een betere inbedding in de curatieve zorg. Omdat de beroepsgroep van mening is dat de huisarts een belangrijke schakel is in preventie, heeft het Nederlands Huisartsen Genootschap in antwoord hierop in 2011 de NHG-Standaard Het PreventieConsult Cardiometabool risico gepubliceerd. ${ }^{1}$ De doelstelling van deze standaard is het voorkómen van hart- en vaatziekten, diabetes mellitus en/of chronische nierschade door vroegtijdige signalering en behandeling van risicofactoren. De richtlijn beschrijft hoe in een zogenoemd 'preventieconsult' bij personen van 45 tot 70 jaar het risico op een van deze aandoeningen kan worden vastgesteld. Het preventieconsult bestaat uit twee stappen. De eerste stap is het (eventueel online) invullen van een vragenlijst die risicofactoren vastlegt en een persoonlijke risicoscore berekent. Indien die score hoger dan de drempelwaarde blijkt te zijn, wordt aangeraden om bij de huisartsenpraktijk het cardiovasculaire risicoprofiel volledig in kaart te brengen (tweede stap), gevolgd door behandeling indien deze is geïndiceerd. De pilotevaluatie van deze standaard in 16 praktijken liet zien dat eenderde van de uitgenodigde patiënten de vragenlijst invult, en dat bij eenvijfde van de respondenten een verhoogd risico wordt gevonden. ${ }^{2}$ Uiteindelijk werd bij één op de vijf van alle mensen die het spreekuur bezochten een nieuwe cardiometabole aandoening gediagnosticeerd.
UMC Utrecht, Julius Centrum voor Gezondheidswetenschappen en Eerstelijns Geneeskunde, Str.6.131, Postbus 8550o, 3508 GA Utrecht: dr. M. Hollander, kaderhuisarts HVZ, postdoc-onderzoeker; D.M. Stol, aiotho; prof.dr. N.J. de Wit, hoogleraar Huisartsgeneeskunde. NIVEL, Utrecht: I.F. Badenbroek, aiotho; M.J.Nielen, senior onderzoeker NIVEL Utrecht/VUmc EMCO Instituut, afdeling Huisartsgeneeskunde en Ouderengeneeskunde Amsterdam: prof.dr. F.G. Schellevis, hoogleraar Huisartsgeneeskunde • Correspondentie: M.Hollander-2@umcutrecht.nl • Mogelijke belangenverstrengeling: niets aangegeven.

\section{ARGUMENTEN GROOTSCHALIGE IMPLEMENTATIE}

Het belang van preventie wordt steeds groter. Door de vergrijzing verwachten we de komende decennia een toename van het aantal patiënten met hart- en vaatziekten, diabetes en nierschade. Bovendien hebben steeds meer mensen een ongezonde leefstijl (slechte voeding, roken en weinig beweging), wat leidt tot een verhoogd risico op cardiometabole aandoeningen. Indien die risicofactoren vroegtijdig worden opgespoord, of de ermee gepaard gaande ziekte in een vroeg stadium wordt herkend, kan behandeling volgen waardoor ziektelast en kosten worden bespaard.

De beste plaats voor preventieve behandeling is de eerste lijn. De huisarts heeft als geen ander zicht op en een band met de praktijkpopulatie en heeft daarom een ideale positie voor preventie op populatieniveau. Indien de zorg voor diabetes en CVRM goed is georganiseerd, is vroegopsporing van chronische ziekten door implementatie van het preventieconsult de ontbrekende volgende stap in de volledige inrichting van de ketenzorg. Implementatie hiervan kan op middellange termijn zorgen voor vermindering van ziekte en sterfte door cardiometabole aandoeningen.

\section{WAAROM NIET? INHOUDELIJKE BEZWAREN}

Momenteel is er een aantal belemmerende factoren voor de implementatie van het preventieconsult. Sommige zijn fundamenteel: bemoeienis met risico en leefstlijl van mensen zou niet in de zorg thuishoren, maar primair een individuele keuze en verantwoordelijkheid van mensen zelf zijn. Waarom zou de huisarts, en de zorg in het algemeen, zich daarmee bemoeien? Hiermee samenhangend blijft het ook onduidelijk wie preventie moet betalen. Moet dit worden betaald uit collectieve middelen of is het de individuele verantwoordelijkheid van de burger? Daarnaast vereist een goed doordacht preventieprogramma meer dan alleen een goed ingericht preventie- en zorgprogramma in de huisartsenpraktijk. Openbare gezondheidszorg, gemeenten en de politiek zullen ook moeten meewerken aan het stimuleren van een gezonde leefstijl. Dit vraagt om een breed draagvlak in de politiek en bij de bevolking, en dat is er nu nog niet. De invloed van preventieprogramma's is beperkt: op de sociale en financiële problemen die een gezonde leefstijl vaak belemmeren heeft de zorg geen invloed. Ook is er onduidelijkheid over het bereik en de impact van het preventieconsult. De huisarts kan niet alle mensen bereiken die het preventieconsult nodig hebben. Alhoewel recent onderzoek dit tegenspreekt, is de algemene gedachte dat de meeste mensen die meedoen bezorgde maar relatief gezonde personen zijn, de zogenaamde 'worried well'. Mensen in een sociaal of psychisch isolement met een verhoogd risico zouden minder snel geneigd zijn om een risicotest en vragenlijst in te vullen, evenals patiënten van niet-Nederlandse afkomst. De beoogde leefstijlverandering blijkt vaak lastig te 
Tabel Criteria van Wilson en Jungner voor gerechtvaardigde screening

- Het moet een ernstig en vaakvoorkomend gezondheidsprobleem betreffen.

- Een algemeen aanvaarde behandeling voor opgespoorde gevallen dient het beloop gunstig te beïnvloeden.

- Er moeten voldoende voorzieningen beschikbaar zijn voor screeningsonderzoek en eventuele behandeling.

- Het natuurlijk beloop van de aandoening moet bekend zijn.

- Er moet een herkenbaar latent stadium zijn.

- Er moet een kwalitatief goede opsporingsmethode beschikbaar zijn.

- De test moet aanvaardbaar zijn voor brede groepen in de bevolking.

- De kosten moeten acceptabel zijn tegen de achtergrond van de baten en middelen die voor de gezondheidszorg beschikbaar zijn.

- Er moet in een zekere mate van continuïteit van het programma voorzien kunnen worden.

realiseren, en moeilijk wetenschappelijk te documenteren.

Het belangrijkste bezwaar is echter dat de doelmatigheid van brede implementatie van het preventieconsult op lange termijn, winst in termen van minder sterfte door cardiometabole aandoeningen, nog niet is aangetoond. Dat is ook voor zorgverzekeraars de belangrijkste reden om de eerste stap van het preventieconsult, het uitnodigen van mensen, nog niet op te nemen in de het basispakket. Zorgverzekeraars vergoeden $\mathrm{nu}$ alleen de consulten die voortvloeien uit het preventieconsult.

\section{EEN VERLAMMENDE IMPASSE}

Er is veel onduidelijkheid omtrent de invoering en de effectiviteit van het preventieconsult. Acceptabele deelname aan preventieprogramma's is een onmisbare voorwaarde voor succes, maar de bereidheid onder de bevolking tot deelname is onduidelijk. En opsporing van cardiometabole risicofactoren en leefstijlaanpassingen leiden pas na langere tijd tot gezondheidswinst. De WHO-criteria voor gerechtvaardigde screening van Wilson en Jungner geven ondermeer aan dat de kosten acceptabel moeten zijn ten opzichte van de baten, en ook dat er een zekere mate van continuïteit van het programma moet worden geboden [tabel]. Duidelijkheid over bovengenoemde factoren in de standaard is bepalend voor hoe Nederlandse huisartsen verdergaan met het preventieconsult. Door onduidelijkheid over de effectiviteit en financiering stagneert de implementatie. De financiering wacht op het bewijs voor kosteneffectiviteit, maar voor het aantonen daarvan is eerst financiering nodig om het preventieconsult in een onderzoekssetting te implementeren en te evalueren. Deze houdgreep leidt tot een verlammende impasse.

\section{INTEGRATE-onderzoek}

- Betrokken partijen: NIVEL Julius Centrum (UMCU), EMGO Instituut (VUmc), NIPED

- Financiers: Zon MW, Lekker Lang Leven (Diabetesfonds, Nierstichting, Hartstichting), Diabetesfonds, Nierstichting, Hartstichting , Innovatiefonds Zorgverzekeraars

- Vraagstellingen:

- Is implementatie van het cardiometabool preventieconsult in de huisartsenpraktijk (kosten)effectief?

- Welke kenmerken van de praktijkorganisatie voorspellen succesvolle implementatie?

- Wat zijn kenmerken van personen die niet deelnemen tijdens verschillende fasen van het onderzoek?

- Welke strategie kan worden toegepast om zoveel mogelijk mensen te laten meedoen?

Voor meer informatie: www.integrateproject.nl.

\section{TIJD VOOR WETENSCHAPPELIJKE EVALUATIE}

Om deze impasse te doorbreken gaat het INTEGRATEonderzoeksconsortium een grootschalig onderzoek in 40 huisartsenpraktijken uitvoeren om inzicht te krijgen in de effectiviteit en kosteneffectiviteit van het cardiometabool preventieconsult. Deelnemers worden minimaal een jaar gevolgd om te evalueren wat het effect van medicatie of leestijlverandering is. Op basis van verandering van het risico gedurende het eerste jaar zal via modellering de potentiële winst in gewonnen gezonde jaren zonder cardiometabole ziekte en sterfte worden berekend.

De uitvoering wordt mogelijk gemaakt door een aantal bij preventie betrokken partijen, zoals ZonMw, het Diabetesfonds, de Hartstichting, Nierstichting Nederland en het Innovatiefonds Zorgverzekeraars. Het onderzoek zal antwoord geven op de vraag voor wie het preventieconsult het meest effectief is en welke patiëntfactoren en factoren in de praktijkorganisatie succesvolle implementatie voorspellen. Indien het preventieconsult cardiometabool risico bewezen (kosten)effectief blijkt te zijn, kunnen de resultaten bijdragen aan de discussie over het preventieconsult door aanbevelingen over de optimale strategie van implementatie en over de bekostiging.

\section{LITERATUUR}

1 Dekker JM, Alssema M, Janssen PGH, Van der Paardt M, Festen CCS, Van Oosterhout MJW, et al. NHG-Standaard Het PreventieConsult Cardiometabool risico. Huisarts Wet 2011;54:138-55.

2 Van der Meer V, Nielen MMJ, Drenthen AJ, Van Vliet M, Assendelft WJJ, Schellevis FG. Cardiometabolic prevention consultation in the Netherlands: screening uptake and detection of cardiometabolic risk factors and diseases - a pilot study. BMC Fam Pract 2013;14:29.

3 Nielen MMJ, Van der Meer V, Assendelft WJJ, Schellevis FG. Eerste ervaringen met het PreventieConsult Cardiometabool risico. Huisarts Wet 2011;54:414-9. 